\title{
The role of Negative Pressure Wound Therapy in the management of orocutaneous fistulas in cancer patients - a case series
}

\author{
Iwona A. Niedzielska, Katarzyna M. Ściskała, Michał M. Bạk, Damian Niedzielski
}

\section{CASE REPORT}

\begin{abstract}
Background: Negative Pressure Wound Therapy (NPWT) is used in the treatment of various wounds. The study demonstrates a novel use of vessel patch as a sealant of mucosal orifice fistulas.

Methods: The study included ten patients with orocutaneous fistulas in the course of treatment of oral malignancies. Patients were divided into treatment (NPWT) and control (conventional dressings) group. In four cases, the vessel patch was applied. We used the Hartmann Vivano system with $50 \mathrm{mmHg}$ to 130 mmHg negative pressure values.

Results: The median age of patients was 61.5 years (range: 31 - 73 years). The median treatment time was 83 days (range: 14 - 272 days). The median total treatment cost was 5.300 EUR (range: 2490 - 7821 EUR) in the NPWT group and 12.000 EUR (range: 3.060 - 22.745 EUR) in the control group.

Conclusion: The use of NPWT is a cost-effective and reasonable method for the management of orocutaneous fistulas and other complications in maxillofacial surgery.
\end{abstract}

Keywords-NPWT, orocutaneous fistulas, cancer,

\section{INTRODUCTION}

T HE frequency of cutaneous fistulas formation after reconstruction surgery of head and neck varies between $2 \%$ to $66 \%$.1 Frederick et al. reported this complication in $3 \%$ of cases in their retrospective study carried out on 1,000 patients with the use of free vascularized tissue grafts! Sousa et al. noted that among patients who underwent a total laryngectomy, the incidence of fistula formation was $15 \%$, and it was the most common complication in this group of patients. The mean time to fistula formation was 3.5 days, with a standard deviation of 13.7 days. Malnutrition, positive surgical margins, the necessity of neck dissection, the presence of tracheostomy, tumor stage, and prior radiotherapy are considered to be contributing factors to fistula formation. However, a mechanistic dependency between those factors and fistula incidence has not been demonstrated. ${ }^{3}$

Moreover, surgical reconstruction promoting insufficient vascular viability of the tissues, poor suturing technique failing to provide watertight connection, and the contamination from the upper gastrointestinal tract contribute to fistula

Manuscript received 28.10.2019; revised 19.12.2019. This work did not receive any financial support.

Author affiliations: Department of Cranio-Maxillofacial Surgery, Medical University of Silesia, Francuska 20/24, 40-027 Katowice, Poland , (IN, KŚ, MB, DN)

*Correspondence to: Michał Bạk: mmwbak@gmail.com formation! $[4$ Orocutaneous and pharyngocutaneous fistulas cause serious inconvenience for patients. Applying dressings or covering them is widely restricted, and they may impede oral feeding. 1

Furthermore, the occurrence of fistulas prolongs hospitalization time, raise therapy costs, and may postpone adjuvant therapy ${ }^{[5}$ There is an agreement that cutaneous fistulas should be initially treated conservatively with antibiotics, wound cleansing with the application of conventional dressings, and transition to enteral feeding $\sqrt[3]{5}$ A fraction of fistulas responds to this type of treatment. Sousa et al. reported successful closure by nonsurgical means in all cases ${ }^{\sqrt[3]{6}} \mathrm{Nev}$ ertheless, McNeal et al. reported that spontaneous closure of pharyngocutaneous fistulas occurred after an average of 50 days (range: $10-120$ days) among all the patients and 24 days (range: 14 - 60 days) in patients who did not receive radiotherapy!6 Still, some fistulas do not respond to conservative treatment and require surgical treatment, 5.7

Lately, the usefulness of Negative Pressure Wound Therapy (NPWT) in the treatment of orocutaneous and pharyngocutaneous fistulas was discussed by Andrews et al ${ }^{8}$ in 2008 , Dhir et al ${ }^{9}$ in 2009, Tay et al ${ }^{10}$ in 2011 in a case report, Tian et al ${ }^{[5}$ in 2013 in a study based on Tay report, Yang et al ${ }^{[4}$ in 2013 and Kojima et al.$^{7}$ in 2015 . In this latest study, Kojima et al. sutured the cutaneous side of fistulas to achieve airtightness and applied negative pressure of $-200 \mathrm{mmHg} \cdot 7$ On the other side, Yang et al. emphasized the necessity of suturing the mucosal side of the fistula. ${ }^{4}$ Tay et al. and Tian et al. achieved the seal on the mucosal side of the fistula with cotton gauze immersed in the dental alginate impression material. 5.10 In this paper, we present a novel method of sealing the mucosal side of the fistula with the use of a nonresorbable vessel patch. The application of the vessel patch facilitates the watertight suturing on the mucosal side of the fistula, thus stopping the salivary leak into the fistula.

This solution has the following advantages:

1) facilitates watertight suturing on the mucosal side of fistula avoiding unnecessary tension,

2) allows watertight suturing in the situation of tissue deficit when it is impossible to repair the defect by primary closure

3) brings together and stabilizes wound margins, and

4) provides a watertight seal, thus stopping the saliva 
leakage independently of the NPWT usage on the cutaneous side.

The last one simplifies the conventional wound care because dressings are loaded with less exudate. It is worth noting that (5) once sutured, the vessel patch stays in place and does not require replacement when the cutaneous dressings are changed (these can be either conventional or NPWT).

We have not found any prior reports on such usage of vessel patches in the literature. Vessel patches or vascular prostheses are commonly used in cardiac and vascular surgery in the treatment of injuries, aneurysms, congenital defects, and repairing defects of vessels and cardiac walls. ${ }^{11}$ They are produced from biocompatible synthetic polymers or autologous, allogenic, or xenogenic pericardium.12 Polyethylene terephthalate (PET), and Polytetrafluoroethylene (ePTFE) have been used in cardiac surgery due to their mechanical properties and satisfactory durability ${ }^{11}[2$ This paper aims to evaluate the usefulness of NPWT and its combination with a vessel patch application in the management of orocutaneous fistulas in head and neck cancer patients.

\section{Materials AND METHOdS}

\section{A. Patients}

The study included patients with orocutaneous fistulas treated in the dep of Cranio-Maxillo-Facial and Oral Surgery of Silesian Medical University in Katowice between 2012 and 2014. Patients were divided into two groups: the treatment group (NPWT) and the control group (conventional dressings).

The inclusion criteria were:

1) the presence of orocutaneous fistula verified with dye test and

2) lack of possibility or indications for surgical management of the fistulas. The study included ten patients.

\section{B. Wound management}

Physicians performed all the wound care procedures. NPWT dressings were changed every two to three days, and the conventional dressings were changed every day. The diagnosis of orocutaneous fistula was based on clinical examination and confirmed by the dye test with iodopovidone. The mucosal orifice of the fistula was flushed with water iodopovidone solution Braunol (B.Braun, Melsungen, Germany). In the presence of an orocutaneous fistula, iodopovidone solution appeared on the skin surface. In all cases, mucosal orifices were identified. In order to seal the mucosal opening of the fistula and to stop the saliva leakage in 4 cases $(1,2,6,7)$ the vessel patch was tightly sutured to the margins of the mucosal orifice with the use of polypropylene monofilament sutures (Dafilon, B.Braun, Melsungen, Germany). We present an application of vessel patch as a mucosal side sealant of orocutaneous fistulas.

The use of the vessel patch allowed us to maintain the pressure necessary to facilitate an effective NPWT in the wound bed. Moreover, in both treatment and control groups, the application of the vessel patch ceased the saliva seepage.
Shape stability of the vessel patch provides stabilization for fistula margins and increases the tendency to intraoral component closure by keeping margins closer to each other. In the control group the cutaneous side of the fistula was managed conventionally with silver dressings Aquacel Ag (ConvaTec, Bridgewater Township, NY, USA), Atraumann Ag (Paul Hartmann, Heidenheim an der Brenz, Germany), alginate dressing Sorbalgon (Paul Hartmann, Heidenheim an der Brenz, Germany) and iodopovidone or $10 \% \mathrm{NaCl}$ compresses. In the treatment group, the NPWT dressing was applied on the cutaneous side of the fistula.

Before the introduction of the NPWT, necrotic tissues were removed from the wounds by surgical necrotomy. We used special wound dressings - Tender Wet (Paul Hartmann, Heidenheim an der Brenz, Germany) or lavaseptics with the use of an aqueous solution of octenidine and phenoxyethanol — Octenisept (Schülke \& Mayr, Norderstedt, Germany). The NPWT system used in this study was Vivano (Paul Hartmann, Heidenheim an der Brenz, Germany) consisting of vacuum producing device VivanoTec, exudate canister VivanoTec, VivanoTec Port with multi-lumen drain and VivanoMed dressing kit. The dressing used in this study was the black microporous polyester polyurethane VivanoMed Foam. The sterile foam dressing was adjusted to wound shape, and then it was sealed with semipermeable Hydrofilm foil. Due to the complex anatomy of the head and neck and the presence of foramina, which reduced the surface available for sticking the foil, it was vital to shave the facial hair and degrease the skin meticulously. The latter was achieved by using Kodan Tinktur forte (Schülke \& Mayr, Norderstedt, Germany). Hydrofilm foil prevents the infection by maintaining the moisture and simultaneously stops the growth of anaerobic bacteria due to its permeability. In order to avoid skin maceration, the skin at the margins was protected with Atraumann Ag (Paul Hartmann, Heidenheim an der Brenz, Germany) or Grassolind (Paul Hartmann, Heidenheim an der Brenz, Germany) dressings. Patients were administered empirical or targeted antibiotics. No drugs reducing salivary output were used. The research was approved by the Medical University of Silesia Local Ethics Board.

\section{Results}

The study included ten patients who developed ten orocutaneous fistulas. The group consisted of seven men and three women with a median age of 61.5 years (range, 31 73 years). Three patients had no comorbidities (3, 6, 10). The rest suffered from cardiovascular diseases. Moreover, one patient (5) was diagnosed with asthma-COPD overlap syndrome and chronic rhinosinusitis; the other one (8) was also treated for non-insulin-dependent diabetes mellitus. One patient also suffered from Osler-Weber-Rendu disease complicated with secondary anemia.

Regarding the type of surgery that led to complications, it can be said that orocutaneous fistulas formed in patients who underwent: (1) segmental resection of mandible with free nonvascularized hip bone graft reconstruction and a locking plate together with selective neck dissection in four cases (1, 
Table I

PATIENT DEMOGRAPHICS AND TUMOR CHARACTERISTICS

\begin{tabular}{|c|c|c|c|c|c|c|c|c|c|}
\hline \# & $\begin{array}{l}\text { Age/ } \\
\text { sex }\end{array}$ & Smoker & Comorbidities & Family history & $\begin{array}{l}\text { Previous } \\
\text { HNSCC }\end{array}$ & Prior RT & Pathology & TNM & Type of surgery \\
\hline 1 & $64 / F$ & $\mathrm{Y}$ & $\begin{array}{l}\text { IHD, HT, } \\
\text { cardiac } \\
\text { arrhytmia }\end{array}$ & $\begin{array}{l}\text { Mother: thyroid } \\
\text { cancer Sister: } \\
\text { CNS tumor }\end{array}$ & No & No & $\begin{array}{l}\text { SCC of the floor } \\
\text { of mouth }\end{array}$ & T4N2cM0 & $\begin{array}{l}\text { Segmental resection of } \\
\text { mandible. Reconstruction } \\
\text { with free nonvascularized } \\
\text { hip bone graft and } \\
\text { reconstruction locking } \\
\text { plate. SND. }\end{array}$ \\
\hline 2 & $65 / \mathrm{M}$ & Former & $\begin{array}{l}\text { IHD, brady- } \\
\text { cardia }\end{array}$ & $\begin{array}{l}\text { Father: laryngeal } \\
\text { cancer }\end{array}$ & $\begin{array}{l}\text { SCC of } \\
\text { cheek }\end{array}$ & $\begin{array}{l}60 \\
\text { Gy } 11 \\
\text { months } \\
\text { earlier }\end{array}$ & $\begin{array}{l}\text { Osteoradionecrosis } \\
\text { of the mandible } \\
\text { body and ramus }\end{array}$ & N/A & $\begin{array}{l}\text { Sequestrectomy and fis- } \\
\text { tula closure. }\end{array}$ \\
\hline 3 & 67/M & Y & No & No & No & No & $\begin{array}{l}\text { SCC of the floor } \\
\text { of mouth }\end{array}$ & T4N2aM0 & $\begin{array}{l}\text { Segmental resection of } \\
\text { mandible. Reconstruction } \\
\text { with reconstruction } \\
\text { locking plate. SND. }\end{array}$ \\
\hline 4 & 73/M & $\mathrm{N}$ & $\begin{array}{l}\mathrm{HT} \text {, cardiac } \\
\text { arrhytmia, } \\
\text { PAD, Post } \\
\text { CABG }\end{array}$ & No & No & Yes* & SCC of the cheek & T2N2bM0 & $\begin{array}{l}\text { Resection of cheek tu- } \\
\text { mor. Segmental resection } \\
\text { of mandible. Reconstruc- } \\
\text { tion with reconstruction } \\
\text { locking plate. }\end{array}$ \\
\hline 5 & $64 / M$ & $\mathrm{Y}$ & $\begin{array}{l}\text { Prostate can- } \\
\text { cer RT treat- } \\
\text { ment }\end{array}$ & No & No & No & $\begin{array}{l}\text { SCC of the floor } \\
\text { of mouth }\end{array}$ & T3N1M0 & $\begin{array}{l}\text { Segmental resection of the } \\
\text { mandible. Reconstruction } \\
\text { with reconstruction lock- } \\
\text { ing plate and Bakamijan } \\
\text { flap. SND. }\end{array}$ \\
\hline 6 & $31 / \mathrm{M}$ & $\mathrm{Y}$ & No & No & No & No & $\begin{array}{l}\text { Ameloblastoma } \\
\text { of the mandible } \\
\text { body in the area } \\
\text { from } 37 \text { to } 32\end{array}$ & N/A & $\begin{array}{l}\text { Segmental resection of } \\
\text { mandible. Reconstruction } \\
\text { with free nonvascularized } \\
\text { hip bone graft and } \\
\text { reconstruction locking } \\
\text { plate. SND. }\end{array}$ \\
\hline 7 & $55 / \mathrm{M}$ & Former & HT & $\begin{array}{l}\text { Mother: CNS tu- } \\
\text { mor }\end{array}$ & No & No & $\begin{array}{l}\text { SCC of the floor } \\
\text { of mouth }\end{array}$ & T4aN2bM0 & $\begin{array}{l}\text { Segmental resection of } \\
\text { mandible. Reconstruction } \\
\text { with free nonvascularized } \\
\text { hip bone graft and } \\
\text { reconstruction locking } \\
\text { plate. SND. }\end{array}$ \\
\hline 8 & $59 / \mathrm{F}$ & $\mathrm{Y}$ & NIDDM, HT & $\begin{array}{l}\text { Mother: } \\
\text { leukemia, } \\
\text { Brother: } \\
\text { laryngeal cancer, } \\
\text { Sister: uterine } \\
\text { cancer }\end{array}$ & No & No & $\begin{array}{l}\text { SCC of the floor } \\
\text { of mouth }\end{array}$ & $\mathrm{T} 2 \mathrm{~N} 2 \mathrm{cM} 0$ & $\begin{array}{l}\text { Segmental resection of } \\
\text { mandible. Reconstruction } \\
\text { with reconstruction } \\
\text { locking plate. SND. }\end{array}$ \\
\hline 9 & 47/M & $\mathrm{Y}$ & $\begin{array}{l}\text { HHT, } \\
\text { secondary } \\
\text { anemia, HT, }\end{array}$ & $\begin{array}{l}\text { Mother and } \\
\text { gradfather: } \\
\text { HHT, Great- } \\
\text { grandfather: } \\
\text { laryngeal cancer }\end{array}$ & No & No & $\begin{array}{l}\text { SCC of the floor } \\
\text { of mouth }\end{array}$ & $\mathrm{T} 2 \mathrm{~N} 2 \mathrm{bM} 0$ & $\begin{array}{l}\text { Resection of tumor of oral } \\
\text { cavity. SND. }\end{array}$ \\
\hline 10 & $59 / \mathrm{K}$ & $\mathrm{Y}$ & No & No & No & $\begin{array}{l}\text { Yes (no } \\
\text { medical } \\
\text { records) }\end{array}$ & $\begin{array}{l}\text { SCC of the floor } \\
\text { of mouth }\end{array}$ & T3N2aM0 & $\begin{array}{l}\text { Segmental resection of } \\
\text { mandible. Reconstruction } \\
\text { with free nonvascularized } \\
\text { hip bone graft and } \\
\text { reconstruction locking } \\
\text { plate. SND. }\end{array}$ \\
\hline
\end{tabular}

ACOS — asthma-COPD overlap syndrome, CABG - coronary artery bypass graft, HHT — Hereditary hemorrhagic telangiectasia, Osler-WeberRendu disease, HT - hypertension, IHD - ischaemic heart disease, NIDDM - non-insulin-dependent diabetes mellitus, PAD - peripheral artery disease, SCC - squamous-cell carcinoma, SND - selective neck dissection, *Interrupted because of reconstruction plate exposure 
Table II

WOUND THERAPY CHARACTERISTICS

\begin{tabular}{|c|c|c|c|c|c|c|c|c|c|}
\hline \# & $\begin{array}{l}\text { Intraoral } \\
\text { site }\end{array}$ & Extraoral site & $\begin{array}{l}\text { Additional treat- } \\
\text { ment }\end{array}$ & $\begin{array}{l}\text { Fistula } \\
\text { forma- } \\
\text { tion } \\
\text { (days) }^{\S}\end{array}$ & $\begin{array}{l}\text { NPWT } \\
\text { time } \\
\text { (days) }\end{array}$ & NPWT settings & $\begin{array}{l}\text { Vessel } \\
\text { patch } \\
\mathrm{Y} / \mathrm{N}\end{array}$ & $\begin{array}{l}\text { Treatment } \\
\text { time } \\
\text { (days) }\end{array}$ & Costs \\
\hline 1 & $\begin{array}{l}\text { Floor of } \\
\text { mouth }\end{array}$ & $\begin{array}{l}\text { Incision in sub- } \\
\text { mental region }\end{array}$ & No & 5 & 31 & $\begin{array}{l}\text { Continuous mode: }-100,-85 \\
\mathrm{mmHg}\end{array}$ & $\mathrm{Y}$ & 31 & $\begin{array}{l}\text { T: } 7.600 € \\
\text { D: } 124 €\end{array}$ \\
\hline 2 & $\begin{array}{l}\text { Mucosa } \\
\text { of cheek }\end{array}$ & $\begin{array}{l}\text { Incision in } \\
\text { submandibular } \\
\text { region }\end{array}$ & No & 3 & 36 & $\begin{array}{l}\text { Continuous mode: }-50,-75,- \\
85,-90 \mathrm{mmHg}\end{array}$ & $\mathrm{Y}$ & $180^{*}$ & $\begin{array}{l}\text { T: } 7.821 € \\
\text { D: } 463 €\end{array}$ \\
\hline 3 & $\begin{array}{l}\text { Retromoral } \\
\text { trigone }\end{array}$ & $\begin{array}{l}\text { Incision in buccal } \\
\text { region }\end{array}$ & No & 7 & 31 & $\begin{array}{l}\text { Continuous mode: }-125 \\
\mathrm{mmHg}\end{array}$ & $\mathrm{N}$ & 39 & $\begin{array}{l}\text { T: } 5.300 € \\
\text { D: } 434 €\end{array}$ \\
\hline 4 & $\begin{array}{l}\text { Floor of } \\
\text { mouth }\end{array}$ & $\begin{array}{lr}\text { Submental region } \\
-\quad \text { formation } \\
\text { of } & \text { suppurative } \\
\text { fistula }\end{array}$ & $\begin{array}{l}\text { Removal of } \\
\text { reconstruction } \\
\text { plate. Surgical } \\
\text { fistula closure }\end{array}$ & $\begin{array}{l}\text { during } \\
\text { RT }\end{array}$ & 38 & $\begin{array}{l}\text { Continuous mode: }-85,-120 \text {, } \\
-130 \mathrm{mmHg}\end{array}$ & $\mathrm{N}$ & 272 & $\begin{array}{l}\text { T: } 2.490 € \\
\text { D: } 533 €\end{array}$ \\
\hline 5 & $\begin{array}{l}\text { Floor of } \\
\text { mouth }\end{array}$ & Neck incision & No & 9 & 14 & Continuous mode $-125 \mathrm{mmHg}$ & $\mathrm{N}$ & 25 & $\begin{array}{l}\text { T: } 3.500 € \\
\text { D:300€ }\end{array}$ \\
\hline 6 & $\begin{array}{l}\text { Floor of } \\
\text { mouth }\end{array}$ & Neck incision & $\begin{array}{l}\text { Surgical fistula } \\
\text { closure }\end{array}$ & 15 & 0 & No NPWT & $\mathrm{Y}$ & 133 & $\begin{array}{l}\text { T: } 3.060 € \\
\text { D: } 13 €\end{array}$ \\
\hline 7 & $\begin{array}{l}\text { Floor of } \\
\text { mouth }\end{array}$ & Neck incision & $\begin{array}{l}\text { Removal of free } \\
\text { bone graft. Surgi- } \\
\text { cal fistula closure }\end{array}$ & 6 & 0 & No NPWT & $\mathrm{Y}$ & 78 & $\begin{array}{l}\mathrm{T}: 22.745 € \\
\mathrm{D}: 7 €\end{array}$ \\
\hline 8 & $\begin{array}{l}\text { Floor of } \\
\text { mouth }\end{array}$ & $\begin{array}{l}\text { Incision in } \\
\text { submandibular } \\
\text { region }\end{array}$ & No & 10 & 0 & No NPWT & $\mathrm{N}$ & 180 & $\begin{array}{l}\mathrm{T}: 12.000 € \\
\mathrm{D}: 57 €\end{array}$ \\
\hline 9 & $\begin{array}{l}\text { Floor of } \\
\text { mouth }\end{array}$ & Neck incision & No & 6 & 0 & No NPWT & $\mathrm{N}$ & 14 & $\begin{array}{l}\text { T: } 7.397 € \\
\text { D: } 8 €\end{array}$ \\
\hline 10 & $\begin{array}{l}\text { Floor of } \\
\text { mouth }\end{array}$ & $\begin{array}{l}\text { Incision in sub- } \\
\text { mental region }\end{array}$ & $\begin{array}{l}\text { Removal of } \\
\text { reconstruction } \\
\text { plate. Surgical } \\
\text { fistula closure }\end{array}$ & 4 & 0 & No NPWT & $\mathrm{N}$ & 83 & $\begin{array}{l}\text { T: } 14.987 € \\
\text { D: } 21 €\end{array}$ \\
\hline
\end{tabular}

$\mathrm{T}$ — total treatment cost, D — dressings cost, RT — radiotherapy group and 463 euro (range, 124 - 1282 EUR) in NPWT group. All above-mentioned values where calculated with the exchange rate of 4,20 PLN for 1 EUR, patient stopped showing up to our outpatient clinic, Time from surgery to fistula formation (days)

$6,7,10)$; (2) segmental resection of mandible with locking plate reconstruction, together with selective neck dissection in cases $(3,4,8)$; (3) resection of squamous cell carcinoma of the floor of the mouth in one case (9); (4) surgical treatment of osteoradionecrosis of mandible caused in the course of adjuvant radiation therapy for oral carcinomas in 2 cases $(2,5)$; $(5)$ segmental resection of mandible with free nonvascularized hip bone graft reconstruction using a locking plate in the course of ameloblastoma treatment in one case (6). Median time from surgery to fistula diagnosis was six days (range, 3 - 15 days). In one case (4), the fistula formed in the course of radiation therapy and the cutaneous orifice revealed as a suppurative fistula in the submental region. In all the other cases, the cutaneous orifice of fistulas formed in surgical incisions.

Patient demographics and tumor characteristics are presented in (Tab. II). Nine of 10 patients were hospitalized due to squamous cell carcinoma or complications of its treatment, whereas one patient (6) was treated because of ameloblastoma of the mandible. Seven patients $(1,3,4,6,7$, $8,10)$ underwent segmental resection of the mandible, two $(2,5)$ underwent sequestrectomy, and one (9) underwent resection of tumor of the oral cavity. Selective neck dissection was performed on seven patients $(1,3,4,7,8,9,10)$. In four cases $(1,6,7,10)$, reconstruction of resected mandible was performed with free nonvascularized hip bone graft and reconstruction locking plate, while in three cases $(3,4,8)$, the reconstruction plate was used standalone. One patient underwent a tracheotomy. Treatment time was defined as the time between fistula diagnosis and complete wound healing recorded in patients' medical history. For one patient (2), recorded treatment time represents the time from fistula diagnosis to the time he stopped showing up to our outpatient clinic has not, and we excluded it from the statistical analysis. The median treatment time was 83 days (range, $14-272$ days) for all patients, whereas, in the NPWT group, it was 94.5 days (range, 31 - 272 days). The median time in the control group was 83 days (range, $14-180$ days). The specific data on wound therapy characteristics are shown in (Tab. II). In two patients in the NPWT group, it was necessary to apply the vessel patch in order to obtain a vacuum seal. Once sutured in place, vessel patch facilitated vacuum generation in wound bed regardless of NPWT dressings changes. Besides, the vessel patch was applied in two patients from the control group, which protected the lumen of fistula from salivary infection.

In all patients from the treatment group, the NPWT system Vivano (Paul Hartmann, Heidenheim an der Brenz, Germany) was used. The continuous mode of therapy was used, and the negative pressure values ranged from $-50 \mathrm{mmHg}$ to -130 $\mathrm{mmHg}$. In one patient (5), additionally, the dynamic mode of therapy was employed with the cycles of 5 minutes at -80 $\mathrm{mmHg}$ and subsequently 5 minutes at $-120 \mathrm{mmHg}$. In one case (2), there was a need to downgrade the negative pressure 
value because of the painful burning sensation reported by the patient. In two patients from the control group $(6,7)$, in whom the NPWT was not employed, and in one patient (4) from the NPWT group, it was necessary to perform additional surgical procedures in order to close the fistulas finally.

Furthermore, for all the patients, we performed the analysis of total treatment costs regarding the cost of hospital stay, operating theater, and dressing materials used. This data is presented in (Tab. II). The median of the total treatment cost for all patients was 7498.5 EUR (range, 3.060 - 22.745 EUR); in the control group, it was 12.000 EUR (range, 3.060 - 22.745 EUR) whereas in NPWT group it was 5.300 EUR (range, 2490 - 7821 EUR). Median of dressing materials cost was 90.5 EUR (range, 7 - 1282 EUR) for all patients, 13 EUR (range, 7 - 57 EUR) in the control group, and 463 EUR (range, 124 - 1282 EUR) in NPWT group. All the values mentioned above were calculated with the exchange rate of 4.20 PLN for 1 EUR.

\section{Discussion}

Nowadays, Negative Pressure Wound Therapy is commonly applied in orthopedic traumatology, soft tissue injuries, management of skin grafts, treatment of pressure ulcers, diabetic foot, venous ulcers, and burns. NPWT also aids in fighting against Surgical Site Infections and treatment of Impaired Wound Healing. ${ }^{[13}$ The literature data on NPWT application in the treatment of cutaneous fistulas in the head and neck region consists of papers by Andrews et al., ${ }^{8}$ Dhir

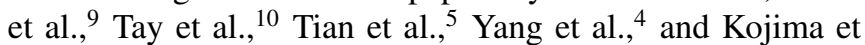
al. ${ }^{7}$ Yang et al. emphasize that the application of NPWT may constitute a useful indicator of mucosal side water tightness, moreover by obliteration of dead spaces, it prevents the damage of large vessels and reduces the total treatment cost. In general, NPWT is depicted by Yang et al. as a convenient treatment modality for orocutaneous fistulas, which facilitates infection control and fistula obliteration.

Tian et al. strongly recommend the use of NPWT in the treatment of orocutaneous fistulas, as none of the patients in their study experienced side effects of NPWT. Moreover, the authors indicate that the development of NPWT complications may result from either inappropriate patient selection or an incorrect NPWT application manner. $[$ Our observation is similar to the authors mentioned above - the median of total treatment cost in the NPWT group is lesser than in the control group, and the complication of NPWT usage in the form of pain and burning sensation was eliminated by more accurate surrounding skin protection. The study by Kojima et al. stands slightly in opposition to Yang et al. and Tian et al. studies, and our observation. They reported the lack of seal of NPWT dressings even when the negative pressure value was lowered to $-200 \mathrm{mmHg}$. As a reason, the authors indicate: (1) complex outline of the wounds; (2) presence of facial hair; (3) the proximity to tracheostomy; (4) the communication of fistula with oral cavity and/or pharynx; (5) reduced tissue elasticity due to prior radiation therapy. Moreover, in this study, the use of NPWT raised the total therapy cost because of elongating the hospitalization time. ${ }^{7}$
Our observation indicates that achieving the water tightness on the mucosal side of the fistula and thorough shaving of facial hair and skin degreasing provided sufficient seal for the dressings. Indeed after three days, the facial hair in males started to impair the dressing seal. Nevertheless, it seems that before the mentioned time, it is irrelevant.

The action of NPWT is based on (1) draining the pathological exudates from the wound bed, 14 (2) reducing the edema, $15,18,20,21,25,28$ and maintaining the humid environment 16 17 25 29 The positive effect of NPWT on leukocytes and fibroblasts migration 22,27$] 30$ and accumulation of growth factors ${ }^{27}[30$ has been demonstrated. Lower concentrations of metalloproteinases (MMPs) ${ }^{31}$ and raised levels of interleukin 8 (IL-8) and vascular endothelial growth factor $(\mathrm{VEGF})^{\sqrt{18}}$ have been observed. Analysis performed by Glass et al. stated that NPWT significantly reduces tumor necrosis factor (TNF) concentration in acute and chronic wounds and interleukin 1 beta (IL-1 $\beta$ ) in acute wounds while having no influence on interleukin 6 (IL-6) levels. NPWT raises interleukin 10 (IL-10) systemic levels and interleukin 8 (IL-8) tissue concentrations. It raises VEGF and basic fibroblast growth factor (bFGF, FGF2) excretion and reduces the expression of metalloproteinases 1 , 2, 9, and 13. ${ }^{32}$ This treatment modality enhances wound blood supply $15+17,[17,[20,23,24,[27,33$ by angiogenesis stimula-

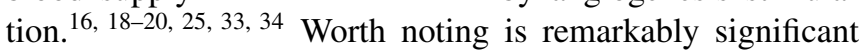
influence of this therapy on proliferation of cells, 18,19$] 25$ granulation tissue formation ${ }^{14}, 20,24,25,29,33,34$ and epithelialization. 28 Moreover NPWT leads to wound area re-

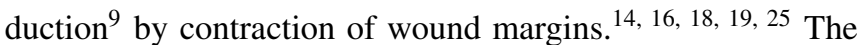

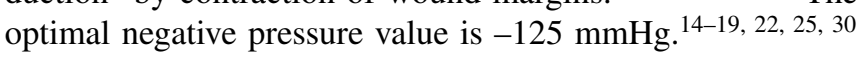
Regarding the expected effect of therapy, this value can be changed. 14 According to literature data immediately upon surgical wound debridement, it is recommended to set negative pressure values between $-150 \mathrm{mmHg}$ and $-200 \mathrm{mmHg}$, however, for the granulation tissue formation stimulation, it is advisable to lower the values to $-110 \mathrm{~mm} \mathrm{Hg}$ to -130 $\mathrm{mmHg}$.21

There are reports on the use of negative pressure values not exceeding $-80 \mathrm{mmHg}$ in order to minimize the possible tissue injury. ${ }^{222}$ Furthermore, the cases were described in which the negative pressure values were set to $-50 \mathrm{mmHg}$ in the therapy of ischemic wounds (Critical Limb Ischemia) providing satisfactory results without wound margins necrosis ${ }^{23}$ According to Malmsjö et al., there are no significant differences in wound healing between negative pressure values of -50 $\mathrm{mmHg},-75 \mathrm{mmHg}$, and $-125 \mathrm{mmHg}$. Furthermore, the blood flow at $-80 \mathrm{mmHg}$ is similar to that at $-125 \mathrm{mmHg}$. In conclusion, the authors suggest the use of higher pressure values in painful wounds with poor blood supply $\sqrt{13}$ Because of the anatomic factors NPWT in the region of head and neck is not straightforward in use; however, it is highly efficient in the treatment of impaired wound healing. Undoubtedly further investigation on the mechanism of action of NPWT is warranted. Likewise, there is little evidence on the use of NPWT in orocutaneous fistulas treatment, and further trials should be conducted. In this paper, we described a novel method of sealing a mucous-end fistula orifice preventing 
the salivary penetration. The dressings in the NPWT group were changed every 2 to 3 days, which turned out to be both cost-effective and convenient for patients.

\section{Conclusions}

The application of Negative Pressure Wound Therapy is a reasonable treatment modality for complications in maxillofacial surgery, including orocutaneous fistulas.

\section{REFERENCES}

[1] P. L. Sadigh, C.-J. Wu, W.-J. Feng, C.-H. Hsieh, and S.-F. Jeng, "New double-layer design for 1-stage repair of orocutaneous and pharyngocutaneous fistulae in patients with postoperative irradiated head and neck cancer," Head $\mathcal{F}$ neck, vol. 38, no. S1, pp. E353-E359, 2016.

[2] J. W. Frederick, L. Sweeny, W. R. Carroll, G. E. Peters, and E. L. Rosenthal, "Outcomes in head and neck reconstruction by surgical site and donor site," The Laryngoscope, vol. 123, no. 7, pp. 1612-1617, 2013.

[3] A. A. Sousa, J. Porcaro-Salles, J. Soares, J. Carvalho, G. Silva, P. Savassi-Rocha et al., "Predictors of salivary fistula after total laryngectomy." Revista do Colegio Brasileiro de Cirurgioes, vol. 40, no. 2, pp. 98-103, 2013.

[4] Y.-H. Yang, S.-F. Jeng, C.-H. Hsieh, G.-M. Feng, and C. C. Chen, "Vacuum-assisted closure for complicated wounds in head and neck region after reconstruction," Journal of Plastic, Reconstructive $\mathcal{E}$ Aesthetic Surgery, vol. 66, no. 8, pp. e209-e216, 2013.

[5] B. Tian, D. Khoo, A. C. Tay, K.-C. Soo, N. C. Tan, H. K. Tan, and N. G. Iyer, "Management of orocutaneous fistulas using a vacuumassisted closure system," Head $\mathcal{E}$ neck, vol. 36, no. 6, pp. 873-881, 2014.

[6] J. N. Mclean, C. Nicholas, P. Duggal, A. Chen, W. G. Grist, A. Losken, and G. W. Carlson, "Surgical management of pharyngocutaneous fistula after total laryngectomy," Annals of plastic surgery, vol. 68, no. 5, pp. 442-445, 2012.

[7] M. Kojima, J. Yokoyama, S. Ooba, M. Fujimaki, T. Anzai, and et al., "Problems associated with vacuum-assisted closure system in postoperative head and neck fistula." J Otol Rhinol, vol. 0, no. 1, 2015.

[8] B. T. Andrews, R. B. Smith, H. T. Hoffman, and G. F. Funk, "Orocutaneous and pharyngocutaneous fistula closure using a vacuumassisted closure system," Annals of Otology, Rhinology $\mathcal{G}$ Laryngology, vol. 117, no. 4, pp. 298-302, 2008.

[9] K. Dhir, A. J. Reino, and J. Lipana, "Vacuum-assisted closure therapy in the management of head and neck wounds," The Laryngoscope, vol. 119, no. 1, pp. 54-61, 2009.

[10] A. Tay, C. Ong et al., "Management of a complex mandibular wound: a case study," Wound Practice $\mathcal{E}$ Research: Journal of the Australian Wound Management Association, vol. 19, no. 3, p. 110, 2011.

[11] A. M. Ostdiek, J. R. Ivey, S. A. Hansen, R. Gopaldas, and S. A. Grant, "Feasibility of a nanomaterial-tissue patch for vascular and cardiac reconstruction," Journal of Biomedical Materials Research Part B: Applied Biomaterials, vol. 104, no. 3, pp. 449-457, 2016.

[12] C. Yang, "Tissue engineering of human cardiovascular patches." Ph.D. dissertation, Charité - University Medicine, Berlin., 2005.

[13] M. Malmsjö and O. Borgquist, "Npwt settings and dressing choices made easy," Wounds International, vol. 1, no. 3, 2010.

[14] M. Zieliński and W. Majewski, "Współczesne koncepcje leczenia ran przewlekłych.” Wounds International, vol. 9, no. 1, pp. 74-81, 2009.

[15] D. A. Caniano, B. Ruth, and S. Teich, "Wound management with vacuum-assisted closure: experience in 51 pediatric patients," Journal of pediatric surgery, vol. 40, no. 1, pp. 128-132, 2005.

[16] M. Shirakawa and R. R. Isseroff, "Topical negative pressure devices: use for enhancement of healing chronic wounds," Archives of dermatology, vol. 141, no. 11, pp. 1449-1453, 2005.

[18] Ł. Woda, Z. Banaszkiewicz, and A. Jawień, "Terapia podciśnieniowa w leczeniu trudno gojących się ran.” Leczenie Ran, vol. 9, no. 4, 2012.
[17] A. Wackenfors, J. Sjögren, R. Gustafsson, L. Algotsson, R. Ingemansson, and M. Malmsjö, "Effects of vacuum-assisted closure therapy on inguinal wound edge microvascular blood flow," Wound repair and regeneration, vol. 12, no. 6, pp. 600-606, 2004.

[19] S. S. Scherer, G. Pietramaggiori, J. C. Mathews, M. J. Prsa, S. Huang, and D. P. Orgill, "The mechanism of action of the vacuum-assisted closure device," Plastic and reconstructive surgery, vol. 122 , no. 3 , pp. 786-797, 2008 .

[20] D. A. Simhaee, A. Marsano, G. M. Fomovsky, G. Niedt, J. K. Wu et al., "Efficacy and mechanisms of vacuum-assisted closure (vac) therapy in promoting wound healing: a rodent model," Journal of Plastic, Reconstructive $\mathcal{E}$ Aesthetic Surgery, vol. 62, no. 10, pp. 1331-1338, 2009.

[21] J. Taradaj, A. Franek, C. Kucio, and K. Walewicz, "Terapia podciśnieniowa (vac) w leczeniu trudno gojących się ran.” Rehabilitacja w praktyce, vol. 3, pp. 42-443, 2010.

[22] M. Miller, "Mcdaniel c," Leczenie rozejścia się rany przy pomocy alternatywnego systemu powierzchniowego wywierania podciśnienia. Leczenie Ran, vol. 4, no. 4, pp. 125-129, 2007.

[23] Y. Kasai, H. Nemoto, N. Kimura, Y. Ito, and N. Sumiya, "Application of low-pressure negative pressure wound therapy to ischaemic wounds," Journal of Plastic, Reconstructive $\mathcal{E}$ Aesthetic Surgery, vol. 65, no. 3, pp. 395-398, 2012.

[24] J. E. Grey, K. G. Harding, R. Mądry, M. Sierociński, J. Strużyna, and P. Wydawnictwo Lekarskie, Leczenie ran $w$ praktyce. Wydawnictwo Lekarskie PZWL, 2010.

[25] C. Huang, T. Leavitt, L. R. Bayer, and D. P. Orgill, "Effect of negative pressure wound therapy on wound healing." Current problems in surgery, vol. 51, no. 7, pp. 301-331, 2014.

[26] I. BABIAK, "Negative pressure wound therapy (npwt) and its role in the treatment of infected wounds in orthopedic practice." Leczenie Ran, vol. 11, no. 1, 2014.

[27] I. Babiak, M. L. Żakiewicz, and M. Luterek, "Zastosowanie opatrunków podciśnieniowych vac w kompleksowym leczeniu otwartych złamań iiib i iiic podudzia z masywnym ubytkiem tkanek miękkich,' Chir. Narz. Ruchu Ortop. Pol, vol. 76, no. 3, pp. 154-160, 2011.

[28] J. P. Stannard, D. A. Volgas, G. McGwin III, R. L. Stewart, W. Obremskey, T. Moore, and J. O. Anglen, "Incisional negative pressure wound therapy after high-risk lower extremity fractures," Journal of orthopaedic trauma, vol. 26, no. 1, pp. 37-42, 2012.

[29] B. MROZIKIEWICZ-RAKOWSKA, A. NOWAK, E. BUCIOR, J. KANIA, K. GŁODAŁA-JAKONIUK, and P. KRASNODĘBSKI, "Zastosowanie terapii podciśnieniowej w leczeniu zespołu stopy cukrzycowej." Leczenie Ran, vol. 11, no. 1, 2014.

[30] I. BABIAK, "Negative pressure wound therapy (npwt) and its role in the treatment of infected wounds in orthopedic practice." Leczenie Ran, vol. 11, no. 1, 2014.

[31] C. M. Mouës, A. W. Van Toorenenbergen, F. Heule, W. C. Hop, and S. E. Hovius, "The role of topical negative pressure in wound repair: expression of biochemical markers in wound fluid during wound healing," Wound repair and regeneration, vol. 16, no. 4, pp. 488-494, 2008.

[32] G. Glass, G. Murphy, A. Esmaeili, L.-M. Lai, and J. Nanchahal, "Systematic review of molecular mechanism of action of negativepressure wound therapy," British Journal of Surgery, vol. 101, no. 13 , pp. 1627-1636, 2014.

[33] S. Lindstedt, M. Malmsjö, J. Sjögren, R. Gustafsson, and R. Ingemansson, "Impact of different topical negative pressure levels on myocardial microvascular blood flow," Cardiovascular Revascularization Medicine, vol. 9, no. 1, pp. 29-35, 2008.

[34] L. Labler, M. Rancan, L. Mica, L. Härter, D. Mihic-Probst, and M. Keel, "Vacuum-assisted closure therapy increases local interleukin8 and vascular endothelial growth factor levels in traumatic wounds," Journal of Trauma and Acute Care Surgery, vol. 66, no. 3, pp. 749757, 2009. 